\title{
Resenha
}

\section{CHAVEIRO, Eguimar Felício; CALAÇA, Manoel; REZENDE, Mônica Cristina da Silva: A dinâmica demográfica de Goiás. Goiânia: Ed. Ellos, 2009. 129 p.}

\author{
Andréia Borges Alencar Rusel - UFG - Goiânia - Brasil \\ andreiabalencar@hotmail.com
}

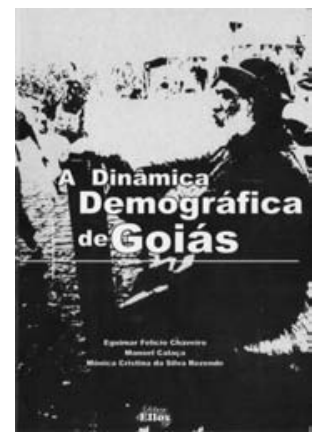

A obra intitulada $A$ dinâmica demográfica de Goiás, dos geógrafos Eguimar Felício Chaveiro, Manoel Calaça e Mônica Cristina da S. Rezende, expõe um estudo acerca da dinâmica demográfica do território goiano. É apresentada, no livro, uma rica exposição de dados secundários sobre a evolução do perfil populacional do estado para o período de 1970 a 2004, assim como, um debate especial a respeito das temáticas sertão, fronteiras e cidades médias em Goiás.

O livro é estruturado em três capítulos precedidos de uma breve introdução. Na introdução os autores destacam a importância de se adotar nos estudos demográficos além das clássicas categorias de análise como fecundidade, migração, distribuição da população no território, mortalidade, etariedade, novas categorias como corporeidade, gênero, etnia, movimento social, etc. Para os autores a incorporação dessas novas categorias cria um "alargamento temático que desafia a investigação demográfica” (p. 12).

Ainda na introdução é apresentado aos leitores o pressuposto teórico que orientou o desenvolvimento do livro:

Não se entende o território goiano sem a dinâmica demográfica que lhe instaura concretude; e não se entende a demografia sem interpretar o território goiano que alimenta a dinâmica da população, em variadas acepções e vertentes. (p. 12)

O primeiro capítulo intitulado de: território e o sujeito social trata da evolução da população goiana. Nesse momento os autores buscam responder às questões como: "tem algum valor compreender a evolução populacional de Goiás? Analisar essa categoria - evolução populacional - tem algum respaldo no pensamento demográfico atualizado? “ (p. 17). Para tal objetivo 
adota-se dois período de analises: Goiás de 1930 até 1970, "período que se refere ao Goiás das políticas expansionistas (construção de Goiânia, Macha para Oeste, CANG, PNDs, os plano Rodoviários, etc)” (p. 18) e Goiás de 1970 até 2000 que:

Representa um outro Goiás, amparado por infra-estrutura consolidada (rodovias, energia elétrica, comunicação), mas cindido (separação de Tocantins); um Goiás que sofre influencia da construção de Brasília; um território com uma modernização conservadora que se articula à economia nacional e se prepara, posteriormente, se aglutinar à economia internacional. (p. 19)

Para os autores a análise do crescimento populacional do estado, nos dois períodos citados, permite uma compreensão da atual dinâmica populacional, assim como das transformações produzidas por estas mudanças. demográficas.

Ainda no primeiro capítulo é analisado as transformações sociais derivadas das transformações espaciais no estado.

Durante a década de 1970, os investimentos realizados em técnicas e em infraestrutura como transporte, comunicação energia elétrica e modernização agrícola, concentrando-se na Mesorregião Sul do Estado, impulsionaram a manutenção de elevadas taxas de crescimento populacional, destacando-se a fixação de parcela da população de baixa renda aos arredores do município de Goiânia, principalmente em Aparecida de Goiânia e Entorno do Distrito Federal. (p. 27)

No segundo capítulo, intitulado O espaço/tempo da estrutura da população, os autores destacam a importância do saber demográfico como um "instrumento de interpretação da estrutura e qualidade social" (p. 36). Um saber estratégico que serve tanto ao Estado e às instituições hegemônicas, como também aos setores de resistência da sociedade, especialmente, aos movimentos sociais.

Baseados em dados estatísticos secundários de órgãos oficiais como IBGE e estudos desenvolvidos pelo Programa das Nações Unidas para o Desenvolvimento disponíveis no Atlas do Desenvolvimento Humano no Brasil, os autores explicam as principais mudanças ocorridas nos padrões de fecundidade, mortalidade e estrutura etária da população goiana. Assim como as diferentes concepções de juventude e velhice.

O terceiro capítulo intitulado de A demografia e o território: unidades e diferencialidades apresenta um estudo sobre o efeito e os impactos do processo migratório no crescimento demográfico do estado. Neste capítulo 
a migração é compreendida como um fenômeno social, conectado aos processo econômicos políticos e culturais.

Os autores apóiam-se em vários estudos teóricos para subsidiar as reflexões entorno da importância do processo migratório no crescimento populacional goiano, especialmente, a partir da década de 1970, período em que se registra queda do crescimento vegetativo em Goiás, fato demonstrado com o capítulo anterior. Apresentam as diferentes modalidades de migração que influenciaram e influenciam a densidade populacional, além de explicar como a migração ocorre e como o território reage a esta dinâmica.

No terceiro capítulo encontramos informações que nos ajudam a compreender a atual distribuição desigual da população, com tendência a concentrar nos centros econômicos e em seus entornos.

O mapa da distribuição da população nos revela uma desigualdade na distribuição populacional, destacando alguns municípios, o que representa a especificidade econômica, política ou cultural imposta por um modelo de desenvolvimento econômico que deu certo e ainda impõe sua forma hegemônica. (p. 87)

Os autores apresentam, também, os fatores históricos que influenciaram na composição da população, como a vinda dos negros e europeus para suprir a necessidade de mão-de-obra, e o movimento ocasionado pela Revolução Industrial que motivou fortemente a migração mundial.

Os autores encerram o capítulo com uma breve redação quanto à migração dos goianos para os países ricos pós-Atlântico, relatando a situação destes sujeitos expatriados.

O livro é uma obra didática e objetiva que apresenta, com clareza, alguns elementos básicos do saber demográfico e das bases conceituais para compreensão da dinâmica demográfica do estado de Goiás.

Andréia Borges Alencar Rusel - Licenciada em geografia pela Universidade Federal de Goiás. 